ENTREPRENEURSHIP AND SUSTAINABILITY ISSUES

ISSN 2345-0282 (online) http://jssidoi.org/jesi/ 2020 Volume 8 Number 2 (December)

http://doi.org/10.9770/jesi.2020.8.2(56)
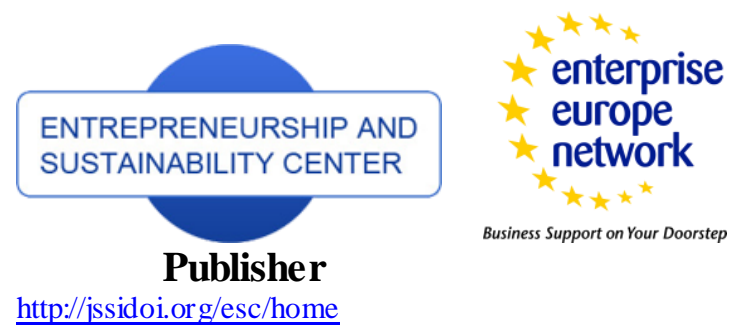

Business Support on Your Doorstep
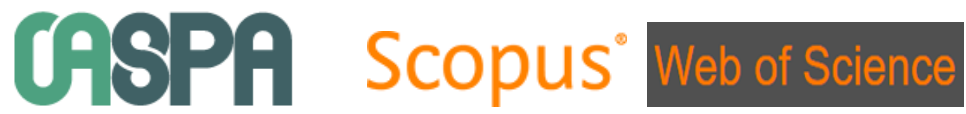

1) Clarivate

Analytics

\title{
THE SCOPE OF LEGAL EXPECTATIONS FROM BUSINESS IN HUMAN RIGHTS: CARROT OR STICK?
}

\author{
Lyra Jakulevičienė ${ }^{1}$, Dovilè Gailiūtė-Janušonė ${ }^{2}$ \\ ${ }^{1,2}$ Mykolas Romeris Law School, Mykolas Romeris University, Ateities Str. 20, 08303 Vilnius, Lithuania \\ E-mail: ${ }^{1}$ lyra.jakuleviciene@mruni.eu; ${ }^{2}$ dgailiute@mruni.eu
}

Received 15 August 2020; accepted 30 September 2020; published 30 December 2020

\begin{abstract}
Although not all businesses acknowledge it, most face issues of human rights in their business operations or relationships. These issues can have positive or negative impacts, whether for their employees, consumers, or communities. In times of crisis, the issues of human rights in business are even more acute - as the COVID-19 pandemic has demonstrated, already having a dramatic impact on people across many supply chains. While the perception that states are responsible for human rights broadly prevails, businesses increasingly face growing expectations to assess, address, and remedy the negative impacts of their activities. Furthermore, developments in the past decade demonstrate the evolution of such expectations into legal requirements and mandatory regulation. States have employed various tools to influence business activities in this field, ranging from soft law to legal requirements both at national and international levels. This article analyses the main European trends of such an evolution within the selected areas of due diligence, non-financial reporting, and investment, and delves into recent developments from the perspective of benefits for business. It explores if the perceived benefits for businesses exclusively serve as a 'stick' that requires compliance, or whether they might extend beyond this.
\end{abstract}

Keywords: business and human rights; UN Guiding Principles; due diligence; business impact; national action plans

Reference to this paper should be made as follows: Jakulevičienè, L., Gailiūtè-Janušonè, D. 2020. The scope of legal expectations from business in human rights: carrot or stick? Entrepreneurship and Sustainability Issues, 8(2), 932-946.

http://doi.org/10.9770/jesi.2020.8.2(56)

JEL Classifications: K33, K38, K20, L14, M14

Additional disciplines: law, economy, business

\section{Introduction}

Most, if not all, businesses face human rights challenges in their operations and business relationships (Baglayan, Landau, McVey, \& Wodajo 2018, p. 12), but not all of them recognize these challenges. A recent survey conducted by the European Union (hereafter - EU) Fundamental Rights Agency highlighted that most human rights violations occur in the context of environmental rights, labour relations, and the field of non-discrimination (Fundamental Rights Agency 2019). Surprisingly, these are among the areas (in particular health, safety, consumer protection, labour, non-discrimination, and the environmental field) where extensive legal requirements 


\section{ENTREPRENEURSHIP AND SUSTAINABILITY ISSUES}

ISSN 2345-0282 (online) http://jssidoi.org/jesi/ 2020 Volume 8 Number 2 (December)

http://doi.org/10.9770/jesi.2020.8.2(56)

Make your research more visible, join the Twitter account of ENTREPRENEURSHIP AND SUSTAINABILITY ISSUES: @Entrepr69728810

under national law exist for businesses (at least in the European region), and these rules are amongst the most protective and effective in the world (European Commission 2015). This contradiction demonstrates that businesses are still not eager to embark on issues of human rights, the reasons behind which might include: the additional administrative burden or perception thereof; the perception of human rights as being far from the business' main goal - profit; limited means of enforcement from the state; low awareness, etc. No less important is the notion that businesses frequently perceive the protection of human rights as being the sole responsibility of the state.

Indeed, states have traditionally been viewed as those responsible for human rights, mainly due to the fact that, firstly, international human rights treaties are signed by states. In other areas of law, such as environmental civil liability, treaties already aim to directly regulate corporations (Bernaz, 2020). Secondly, international and European bodies have, over the years, developed case-law that provides for a state's obligations to protect human rights, covering not only its own actions or inactivity but, through the concept of positive obligations, also extending to ensure that human rights are not violated by private subjects or legal entities, including companies (Wilson, National Union of Journalists and Others v. the United Kingdom 2002, paras. 41, 48; Moreno Gómez v. Spain, 2004, paras. 55, 62; Cabal and Pasini Bertran v. Australia 2003, para. 7.2, etc.). This includes the human rights of individuals in the value chains of businesses supplying goods and services to the state, (Maastricht Guidelines 1997, para. 18; United Nations Committee on Economic, Social and Cultural Rights 2012).

As states are not in direct control of the activities of private companies, they face the challenge of ensuring observance of human rights in the private sphere related to business. For this purpose, they have employed various tools to influence the activities of businesses in this field, ranging from soft law to legal requirements both at the national and international level. At the national level, states have adopted various legislative requirements with regard to labour standards, non-discrimination, privacy protection, and others, and promoted so-called 'responsible' businesses through various incentives. In last decade, a number of states have introduced National Action Plans on Business and Human Rights (hereafter - the NAPs), which include expectations placed on businesses to embed human rights in their policies, practices, and reporting. For instance, Lithuania adopted its first NAP in 2014 as a soft law instrument (Lithuania's Action Plan 2014), and has been elaborating on a new one in 2020 - this time likely to be approved as a normative act. Also, the development of various other soft law instruments on due diligence, supply chain management, public procurement and the like have intensified, and in certain cases evolved into, legislative initiatives binding business entities.

At the same time, some authors argue that businesses have direct obligations under existing international law, although these are limited and wholly dependent on the state's further actions of implementation and enforcement through the concept of the partial legal personality of businesses in international law (Latorre 2020, pp. 56-83). Moreover, the European Court of Human Rights tends, in some cases, to directly attribute duties to protect human rights to non-state actors (Von Hannover v. Germany 2004). However, up until now one cannot find any reference to the direct international human rights obligations of business entities in international law (De Brabandere 2018; Šaltinyte 2020, p. 226). Instead, businesses have a 'responsibility to respect' human rights - that is, to 'do no harm' (Morris 2020, p. 15). At the international level, soft law instruments, such as the United Nations (UN) Guiding Principles on Business and Human Rights (hereafter - UNGPs, UN Guiding Principles), have not yet turned into legal requirements for businesses, despite recent work within the UN Human Rights Council on the Draft Convention on Business and Human Rights.

Whichever concept we would follow, it is undeniable that the expectations placed on businesses to observe human rights have been increasing in recent years. In times of crisis, issues of human rights in business are even more 


\section{ENTREPRENEURSHIP AND SUSTAINABILITY ISSUES}

ISSN 2345-0282 (online) http://jssidoi.org/jesi/ 2020 Volume 8 Number 2 (December)

http://doi.org/10.9770/jesi.2020.8.2(56)

Make your research more visible, join the Twitter account of ENTREPRENEURSHIP AND SUSTAINABILITY ISSUES: @Entrepr69728810

acute, as the COVID-19 pandemic has already had a dramatic impact on people in many supply chains (UN Working Group on Business and Human Rights 2020). Alas, what is the scope of those legal expectations, and what impact will such expectations have on business activities? Can businesses benefit from embedding human rights into their activities, or only ensure compliance with emerging legal regulations? This article investigates these questions. The aim of this article is to analyse how the most recent European legal developments related to upholding human rights in business activities shape the scope of expectations that businesses might face now and in the near future. This aim is composed of two objectives: a) to analyse the most recent European tendencies in creating legal expectations placed on businesses, alongside emerging legal requirements; b) to examine whether emerging regulation and legal expectations to embed human rights create benefits for businesses that extend beyond formal regulatory compliance.

The dialogue between business and human rights mainly concerns assessing the impacts that businesses have on human rights. This includes risks created through businesses' own activities or as a result of their business relationships, including suppliers they outsource to (UN Guiding Principles, principle 18). However, the term is also closely related to corporate social responsibility (hereafter-CSR), which is voluntary in nature. Conversely, the concept of business and human rights largely evolves from the mandatory commitments of states under international law, but also the developing legal expectations of states, stakeholders (e.g. investors), or society at large for businesses to observe standards of human rights. The concept of corporate social responsibility thematically overlaps with the notion of business and human rights, but is much broader in scope than human rights alone (Čertanec 2019, p. 109; for a detailed description of the relationship between the concepts, see European Commission 2019). The issues analysed in this article are widely explored by various authors (Ramasastry 2015; Bernaz 2017; McCorquodale, Smit, Neely, \& Brooks 2017; Buhmann \& Wettstein, 2017; also see the works of human rights experts such as John Gerard Ruggie, Michael K. Addo, Jena Martin, and others) who mostly focus on particular aspects of this topic, while this paper aims to place businesses in a broader context of trends, and examine whether it is beneficial for businesses to go further than simply abiding by rising requirements. It considers the trends of recent years, and examines the setbacks and benefits of processes where expectations have turned, or are beginning to turn, into legal requirements. From the methodological point of view, this article is built around an analysis of recent legislative and jurisprudential developments at the EU and national levels, and relies on doctrine, the reports of international organisations, and empirical data from various sources. The first part of the article examines the processes in selected areas where the evidence of change between expectations and legal requirements placed on business regarding human rights could be found, and the consequences of these developments where it is possible to trace a record of them. Secondly, the authors provide insights into some of the benefits of these developments by using current examples and exploring whether they add tangible value for businesses or serve only as beneficial in terms of regulatory compliance.

\section{Between lawful expectations and legal requirements}

At the European level, recent trends demonstrate the development of legal requirements in the area of businesses and human rights with regard, but not limited, to: due diligence, non-financial reporting, and investment. Firstly, the legal environment in Europe has changed since 2011, when 'human rights due diligence' was formally conceptualized in the UN Guiding Principles that called on companies to identify, prevent, mitigate, and account for how they address their impacts on human rights (Principle 15(b)). However, there has been little effectiveness observed in the voluntary commitments regarding human rights compliance in the supply chain. For instance, according to a recent study in the German government report of July 2020, companies do not voluntarily do enough for human rights. It also states that not even a fifth of the companies surveyed voluntarily abide by human rights standards (Aryobsei \& Scherb 2020). 


\section{ENTREPRENEURSHIP AND SUSTAINABILITY ISSUES}

ISSN 2345-0282 (online) http://jssidoi.org/jesi/ 2020 Volume 8 Number 2 (December)

http://doi.org/10.9770/jesi.2020.8.2(56)

Make your research more visible, join the Twitter account of ENTREPRENEURSHIP AND SUSTAINABILITY ISSUES: @Entrepr69728810

At the EU level, the requirement of due diligence has been developing in the direction of emerging legal regulation. Having started from a sectorial approach in 2010 and 2017 by including the requirement for due diligence as mandatory one (Regulation (EU) 995/2010, Regulation (EU) 2017/821), the EU has a strong commitment to expand it to other sectors. The European Council Conclusions on the EU priorities in the UN human rights forums adopted on 17 February 2020 highlight the focus on due diligence initiatives, among other priorities. As will be demonstrated later, the trend for mandatory due diligence follows also from the financial sector and the expectations of investors. On 29 April 2020, the European Commission confirmed its commitment to introduce mandatory assessment of the impacts of business activities and supply chains on the environment and human rights (European Commission 2020). The Commission will prepare draft legislation by 2021. These developments are in parallel to national ones, where some legislators establish a legally binding obligation for parent companies to identify and prevent adverse human rights and environmental impacts resulting from their own activities or those of companies that they control, and from the activities of their subcontractors and suppliers with whom they have an established commercial relationship. France was the first country to adopt the due diligence requirement in its Duty of Vigilance Law in 2017, followed by the Netherlands with the Child Labour Due Diligence Law in 2019, and various other governments are now considering legislative proposals (e.g. Austria, Luxembourg) (Business \& Human Rights Resource Centre, n.d.). In Switzerland, the Responsible Business initiative has been launched and its counterproposal, the parliamentary initiative for mandatory human rights due diligence, was approved on 5 June 2020 (Business \& Human Rights Resource Centre 2020b). However, as the members of the Responsible Business Initiative rejected this counter-proposal, there will be a public referendum in late 2020 on this issue (European Coalition for Corporate Justice 2020). Germany will soon be introducing the Supply Chain Act, obliging companies to comply with human rights and environmental standards by law (Schenk, Thorhauer, et al. 2020).

At the same time, research demonstrates that the commonly used tools of due diligence are not very effective at improving respect for human rights (see the research of Locke 2013; Barrientos \& Smith 2007; Lindholm, EgelsZandén, \& Rudén 2016; Curley 2020; Alliance for Corporate Transparency 2019, pp. 98-99). Among the reasons for this are: the notion that due diligence is misunderstood by many companies as a mere reporting obligation (Gregor \& Houston 2020); and the idea that many companies do not have the necessary expertise to implement effective human rights due diligence, whilst the right expertise can also be difficult to find externally (UN Working Group on Business and Human Rights 2018). Another reason that has been identified is the growing complexity of corporate structures, which complicates the implementation of due diligence tools not only in the parent/controlling company, but within its business relationships as well (CIDSE 2013, p. 3). Moreover, states are not always willing or able to meet their duty to protect (CIDSE 2018, p. 5). Therefore, the development of new legal requirements at the EU level should consider and address these drawbacks of the new legislation, in particular by improving: understanding of the value of the requirements; the relationship between materiality and reporting (i.e. what exactly the companies do); and enforcement.

Another trend of rising expectations from businesses is related to non-financial reporting, where mandatory requirements have existed since 2014 and are further developing. EU Directive 2014/95/EU of the European Parliament and of the Council of 22 October 2014 - amending Directive 2013/34/EU, as regards the disclosure of non-financial and diversity information by certain large undertakings and groups (also called the EU NonFinancial Reporting Directive) - embodied the duty of large companies from 2018 onwards to annually publish information on non-financial issues, including on the risk of negative impacts on human rights which are directly related to the activities, products, services, and business relations of the company. However, one recent study demonstrated that, of the 1,000 companies assessed, almost $57 \%$ report on risks related to human rights, but only 


\section{ENTREPRENEURSHIP AND SUSTAINABILITY ISSUES}

ISSN 2345-0282 (online) http://jssidoi.org/jesi/ 2020 Volume 8 Number 2 (December)

http://doi.org/10.9770/jesi.2020.8.2(56)

Make your research more visible, join the Twitter account of ENTREPRENEURSHIP AND SUSTAINABILITY ISSUES: @Entrepr69728810

around 4\% report on concrete measures in this regard (Alliance for Corporate Transparency 2019, p. 70). According to the authors, general human rights reporting requirements are not an effective tool for ensuring the disclosure of information that can help to assess a company's management of the individual risks of human rights impacts, and by extension of whether its business conduct is responsible (Alliance for Corporate Transparency 2019, p. 70). The European Commission announced in its Communication on the European Green Deal in 2019 that companies and financial institutions should improve their disclosure of non-financial information, and it plans to revise the Non-Financial Reporting Directive in 2020 as part of a strategy to strengthen the foundations for sustainable investment. This demonstrates that, despite the existing legal requirements, the users of this information (mainly investors and civil society organisations) are demanding more and better information from companies about their social and environmental performance and impacts. This also reflects global trends, with a wide variety of different organisations and stakeholders calling for consideration of a new regulatory approach to non-financial reporting (European Commission 2020).

The third area of development for human rights expectations placed on businesses is in the financial sector. There have been developments both in terms of expectations from investors and the requirements that have been rising for clients in the financial sector. Since the primary obligation to observe and ensure respect for human rights lies with the host state, foreign investors cannot be said to be the direct holders of human rights obligations under international law. The obligations foreign investors have are essentially based on domestic civil or criminal law (De Brabandere 2018, p. 5). This is in line with the primary objectives of traditional investment treaties: to grant rights to foreign investors rather than impose obligations on them (Dubin 2018). Investment tribunals, so far, have also contested the notion that dealing with human rights issues in investment disputes falls within their jurisdiction (De Brabandere 2018, p. 9). For example, when Argentina filed a counterclaim regarding the investor's breach of the human right to water in the Urbaser v. Argentina case, the tribunal concluded that Argentina's claim could not be accepted, as the human right to water created obligations for states only (Urbaser and Consorcio de Aguas Bilbao v. Argentina 2016, para. 1210). At the same time, the arbitrators considered that 'the situation would be different in case an obligation to abstain, like a prohibition to commit acts violating human rights[,] would be at stake. Such an obligation can be of immediate application, not only upon States, but equally to individuals and other private parties' (para. 1210). Despite the traditional objectives of investment treaties, there have been some examples where indirect clauses were provided in investment treaties through CSR as a self-regulating technique (Canada-EU Comprehensive Economic Trade Agreement; Dubin 2018). The UN Conference on Trade and Development (UNCTAD) World Investment Report 2018 notes that most of today's new international investment agreements include sustainable-development-oriented reform elements, and finds remarkable differences in these agreements between 2000 and 2017 in that the newer ones explicitly recognize health, safety, and environment standards (UNCTAD, 2018). In its 2020 report, the UNCTAD confirms that recent treaties increasingly incorporate aspects of sustainability (UNCTAD 2020, p. 19). Although human rights obligations for foreign investors are explicitly included in investment treaties only rarely, because the primary objective of traditional investment treaties is to grant rights to foreign investors rather than impose obligations on them, there are several recent examples of investment treaties containing clauses which refer to the obligations of foreign investors in the area of human rights (De Brabandere 2018, p. 10). For instance, the Intra-MERCOSUR Agreement contains "a "best efforts" obligation for investors to respect the human rights of the people involved in investment activities, and to promote the building of local capacity and the development of human capital' (Baglayan et al. 2018, p. 29). Other examples include the 1990 EC-Argentina cooperation agreement, the 2008 EU-Cariforum agreement, and the Cotonou Agreement (Bartels 2014). However, direct clauses in investment treaties often use weak language or are relatively weak in substance (Dubin 2018). For instance, Article 24 of the Pan-African Investment Code uses conditional verbs ('should') to encourage investors to comply with internationally recognized human rights laws (African Union Commission 2016). At the same time, one can 
ENTREPRENEURSHIP AND SUSTAINABILITY ISSUES

ISSN 2345-0282 (online) http://jssidoi.org/jesi/ 2020 Volume 8 Number 2 (December)

http://doi.org/10.9770/jesi.2020.8.2(56)

Make your research more visible, join the Twitter account of ENTREPRENEURSHIP AND SUSTAINABILITY ISSUES: @Entrepr69728810

conclude that the emerging provisions in investment treaties reflect a new approach that might develop in the future. Furthermore, investment treaties may deny protection to foreign investors of the other party that have engaged in conduct leading to a violation of human rights (UN Committee on Economic, Social and Cultural Rights 2017, para. 50).

Besides the developing requirements for investors on human rights, they themselves increasingly direct their investments into activities that are not harmful and that require companies to prevent, mitigate, or remedy impacts where they occur (Alliance for Corporate Transparency 2019, p. 71). Thus, while more investors are considering sustainability and long-term options, investor scrutiny is increasing in capital allocation decisions (Baglayan et al. 2018, p. 10). In September 2019, the Principles of Responsible Banking were adopted at the global level by one third of banks worldwide, which, among banks' internal commitments to evaluate and manage their impacts on people and environment, also call for banks to encourage sustainable practices among their clients and customers (UN Environment Programme Finance Initiative 2019, Principle 3). Moreover, in April 2020, over 100 investors called for the responsibility of economic actors to respect human rights, and that human rights due diligence is a key requirement for companies to meet this responsibility. They expressed expectations that governments adopt binding human rights due diligence requirements where corporate voluntary action leaves gaps in human rights protection (Business \& Human Rights Resource Centre 2020a). Meanwhile, the EU is progressively considering requirements for the financial system that support the EU's climate and sustainable development agenda. In 2018, the European Commission adopted the Action Plan: Financing Sustainable Growth, which provided a roadmap by setting out the role of finance in achieving a well-performing economy that delivers on environmental and social goals. It also called for the development of a taxonomy of sustainable activities, which the banking sector should foster and deploy as the basis for a future EU taxonomy in legislation (UN Environment Programme Finance Initiative 2019, p. 4).

In conclusion, the evolution of expectations towards legal regulation for businesses in the areas of human rights analysed range from soft law, to partial regulation (mainly reflected by the sectorial or business-type approach), to full regulation (mandatory provisions for all). As can be seen from the Figure 1, full regulation is still not achieved in the areas analysed. While human rights due diligence is most advanced in terms of legal regulation, so far mandatory requirements have not attained a wide recognition at the national (few examples only) or the EU levels. At the same time, considering the EU political commitments, the prospective regulation in this area is most realistic (EU level). 
ENTREPRENEURSHIP AND SUSTAINABILITY ISSUES

ISSN 2345-0282 (online) http://jssidoi.org/jesi/ 2020 Volume 8 Number 2 (December)

http://doi.org/10.9770/jesi.2020.8.2(56)

Make your research more visible, join the Twitter account of ENTREPRENEURSHIP AND SUSTAINABILITY ISSUES: @ Entrepr69728810

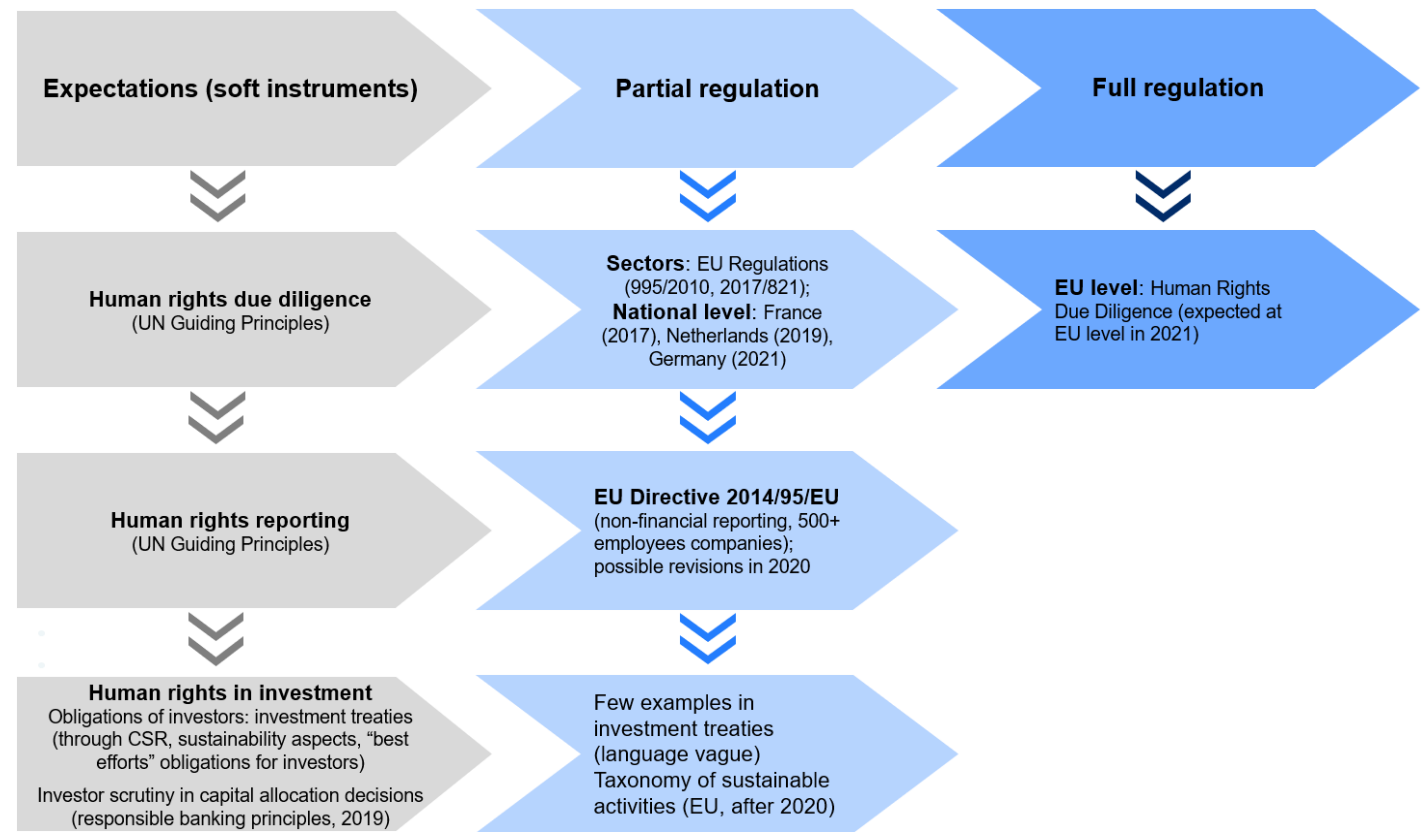

Figure 1. The evolution of expectations into regulation in the areas of human rights due diligence, reporting, and investment.

Source: authors

\section{The benefits of integrating human rights into businesses policies and practice}

The benefits for businesses stemming from the integration of human rights practices have been extensively documented and analysed (Parella 2019; Bonfanti 2019 and others), and were consolidated in the 'Good Business: The Economic Case for Protecting Human Rights' report in 2018 (hereinafter - the Good Business Report; Baglayan et al.). This report was a first step towards building more evidence-based research on the so-called 'business case' for corporate human rights responsibility, and it summarised the key economic drivers for businesses in human rights in the four areas illustrated in Figure 2. 
ENTREPRENEURSHIP AND SUSTAINABILITY ISSUES

ISSN 2345-0282 (online) http://jssidoi.org/jesi/ 2020 Volume 8 Number 2 (December)

http://doi.org/10.9770/jesi.2020.8.2(56)

Make your research more visible, join the Twitter account of ENTREPRENEURSHIP AND SUSTAINABILITY ISSUES: @ Entrepr69728810

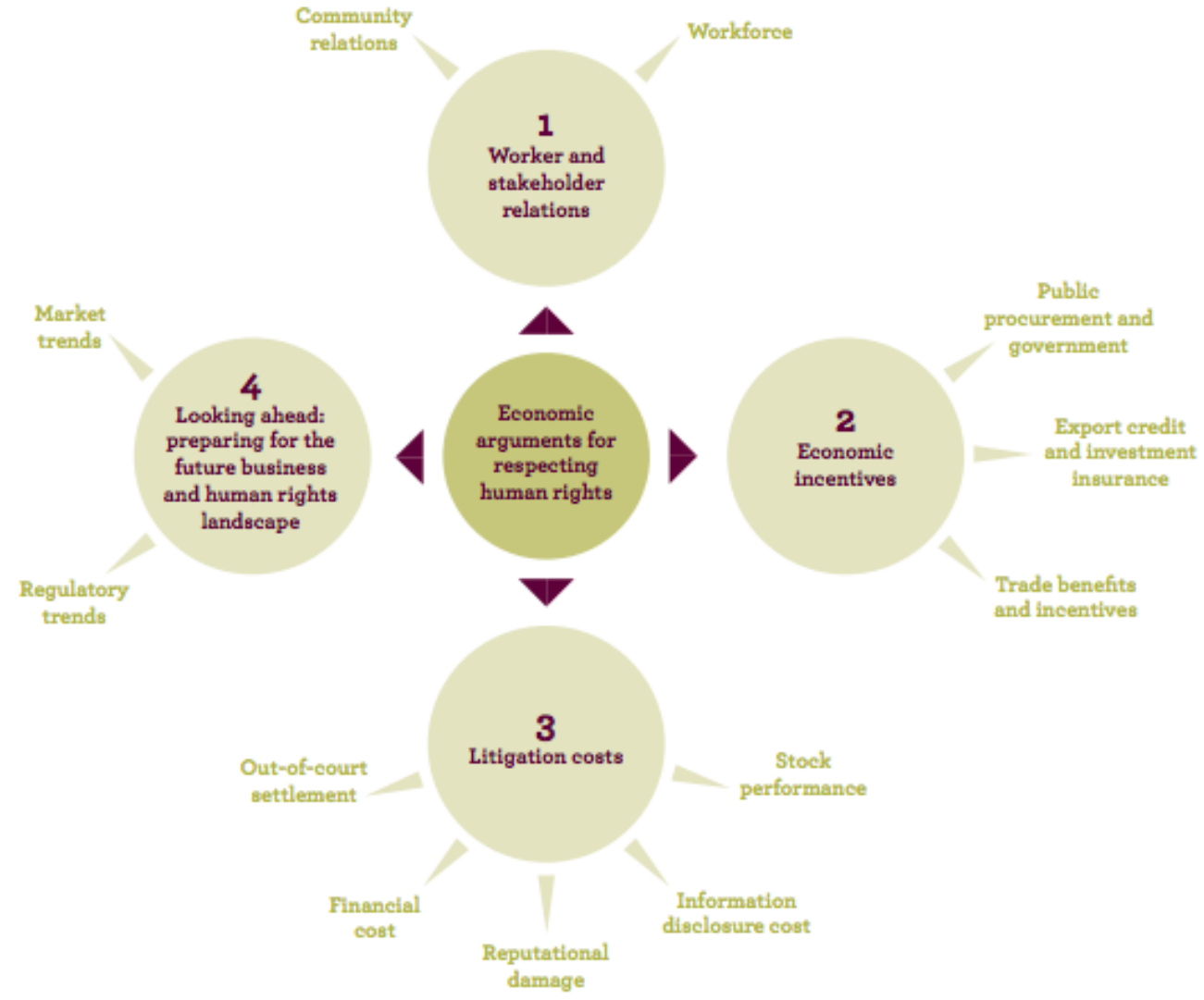

Figure 2. Key economic drivers for businesses in respecting human rights.

Source: Baglayan et al., 2018, p. 17

Since this report, there have been a number of developments that highlight the evidence of benefits for businesses - those of an economic nature in particular. The report highlighted two dimensions of benefits: a) the reduction of cost and risk (worker loyalty and productivity and reducing risks of litigation and to reputation); b) competitive advantage (procurement and investment).

The issue of business and human rights is sometimes perceived as an issue relevant for multinational companies only. For instance, some companies claim that they operate in the EU, where labour regulations are overemphasized and there is no issue of human rights in this sphere in the region (based on the authors' own encounters with business associations and companies in Lithuania). This is not true, as each company, large or small, is routinely faced with human rights issues. First of all, companies increasingly invest in foreign states where human rights and corruption concerns exist; thus, it might be useful to have due diligence procedures in order to assess the risks involved. These measures allow businesses to assess and manage potential risks in a timely manner, and to ensure the preservation of their reputation in risk markets. The formalizing of a common piece of human rights due diligence legislation at the European level, as we have seen in part I of this paper, could come with an additional benefit. It would level the playing field - or at least ensure that all businesses incur the same costs with regards to reinforcing their management systems and practices. This, in turn would create legal certainty. The resulting unity is expected to help corporations gain the necessary traction and leverage to address 


\section{ENTREPRENEURSHIP AND SUSTAINABILITY ISSUES}

ISSN 2345-0282 (online) http://jssidoi.org/jesi/ 2020 Volume 8 Number 2 (December)

http://doi.org/10.9770/jesi.2020.8.2(56)

Make your research more visible, join the Twitter account of ENTREPRENEURSHIP AND SUSTAINABILITY ISSUES: @Entrepr69728810

systemic issues across their supply chains (Dillon 2020). Secondly, due diligence could help to avoid or minimize legal suits. A review of 151 litigation cases showed: a rapidly increasing trend in the frequency of these lawsuits; steadily rising direct financial costs; and that companies are increasingly opting for out-of-court settlements, despite the substantial expense associated (Baglayan et al. 2018, p. 10). Recently, a few important judgments on human rights issues in business have been issued by the courts in Europe. The judgment of the United Kingdom (UK) Supreme Court of 10 April 2019 in Vedanta Resources PLC v. Lungowe confirmed that a parent company can be liable for the operations of its subsidiary in the English courts, despite the fact that harm to the local population by polluting water occurred in Zambia. Thus, there is the possibility for non-UK claimants to bring claims against them in English courts (Vedanta Resources Plc and Konkola Copper Mines Plc v. Lungowe and Others, 2019, paras. 53-54). On 1 May 2019, the Dutch court ruled in Kiobel v. Shell that it has the jurisdiction to determine whether Royal Dutch Shell was complicit in the 1995 Nigerian government's execution of the applicants' husbands - part of the Ogoni 9 activists-who contested Shell's operations and the Nigerian government over the effects of oil pollution (para. 4.23). Differently from previous lawsuits in the United States on the same subject based on tort law, this lawsuit aims at engaging the Shell concern directly in a lawsuit on the infringement of the human rights included in the African Charter on Human and Peoples Rights (ACHPR) and the Nigerian constitution. The trend is that companies now face an increasing risk of legal action and the economic costs it entails, because corporate human rights litigation is costly in terms of finance, reputation, and time (Baglayan et al. 2018, p. 41). In 2018, the Good Business Report identified five types of costs related to human rights lawsuits: financial cost; out-of-court settlement; information-disclosure cost; reputational damage; and potential stock-price decline. As to reputational damage, bad publicity subsequent to a lawsuit often damages the public image of the firm regardless of the final ruling (Baglayan et al. 2018, p. 53).

Companies that export goods and services need to be aware that there are developments in the field of export credits, which add further economic incentives or disincentives for respecting or not respecting human rights. States may refuse access to export credits and other forms of state support in case of human rights issues, thus compliance with requirements may ensure advantage for responsible companies (UN Committee on Economic, Social and Cultural Rights, 2017, para. 15). Although little research has been conducted on the effects of these opportunities, the risks of non-compliance are evident (Baglayan et al. 2018, p. 10).

Those companies that do not invest and not operate in risk countries might be procuring raw materials, products, or services in its global supply chain, thus human rights prevention measures assist in evaluating and managing risks in that chain and in ensuring the reputation of the company. Such risks may include legal (incurring liability for human rights abuses), financial (costs associated with delays in contract delivery, re-running procurement exercises, or remediating harm to victims), or reputational risks. However, if addressed effectively, such risks may become opportunities (Morris 2020, p. 10).

Apart from avoiding the negative consequences of not observing human rights, a company's pro-active role in embedding human rights in its business can lead to additional advantages, including through the economic incentives that public agencies can employ. This is particularly true for companies that aim to attract investment, participate in stock exchanges, and obtain funding from national and international funds, as they are viewed more favourably when they have human rights policies and implement concrete measures thereon (Baglayan et al. 2018 pp. 29-40). Investors assess such companies more positively when they implement human rights measures in business activities, as confirmed by the Responsible Banking Principles, signed by banks in September 2019, which demonstrates their commitment to sustainable business - also including human rights (UN Environment Programme Finance Initiative 2019). Inversely, being seen to create problems for communities or the environment can repel investors. Among recent examples of this effect is the Grigeo company in Lithuania, the 


\section{ENTREPRENEURSHIP AND SUSTAINABILITY ISSUES}

ISSN 2345-0282 (online) http://jssidoi.org/jesi/ 2020 Volume 8 Number 2 (December)

http://doi.org/10.9770/jesi.2020.8.2(56)

Make your research more visible, join the Twitter account of ENTREPRENEURSHIP AND SUSTAINABILITY ISSUES: @Entrepr69728810

share price of which dropped by almost 30 percent following environmental damage caused to the local population as a result of allegedly negligent behaviour with water waste management at the beginning of 2020 (Blekaitis 2020). Furthermore, states also aim to promote responsible companies. For instance, the Swedish government publishes examples of responsible companies, as investors more favourably regard the investment climate in such countries (Sustainable Business in Sweden, n.d.).

As the utilisation of human rights standards in public procurement contracts has become common in countries implementing the UNGPs (Baglayan et al. 2018, p. 10), companies may also possess advantages in national and international tenders, where those capable of demonstrating performance as per high social standards are more favourably considered. This may provide a competitive advantage, in particular within social and sustainable public procurement processes. Increasingly, governments are using economic leverage as a tool to enhance compliance with human rights, as well as environmental and labour standards, by conditioning conveyance of economic benefits upon corporations' performance in these areas (p. 29). EU procurement laws contain an overarching 'social clause' that requires EU Member States to take appropriate measures to ensure, in the performance of a contract, that economic operators comply with the applicable environmental, social, and labour law obligations, including ILO Conventions (Article 18 of the Directive 2014/24/EU). More specifically, they cover: the requirement to exclude bidders that have been convicted of child labour or other forms of trafficking in human beings (Article 57(1)); the possibility to exclude bidders due to non-compliance with environmental, social, or labour law obligations (Article 57(4)); and, for the first time, social considerations in the awarding phase. Article 69 requires contracting authorities to reject tenders that are abnormally low due to poor human rights standards, in case the supplier is unable to satisfactorily account for the low level of the price (Morris 2020, p. 30). These developments are supported at the national level, where more and more states are now adopting national action plans on sustainable public procurement where the social element is informed by human rights (Morris 2020, p. 34-35). For example, Belgium's Public Procurement Act of 2017 requires that suppliers and sub-contractors comply with environmental, social, and labour laws, and failure to comply with this requirement may serve as a ground for exclusion. Switzerland's updated National Action Plan 2020-2023 on business and human rights refers to the Federal Act on Public Procurement, which envisages that the contracting authority may require bidders to comply with other core international labour standards, provide proof of compliance, and agree to audits (Morris 2020, p. 31). Companies that have already embedded these practices would find themselves at a competitive advantage in terms of meeting such requirements. Incentives are also developing at the municipal level. In 2020, the City of Malmö in Sweden introduced a scheme to analyse and prioritise procurement exercises with the greatest environmental and social impact. For example, a procurement exercise related to transport will achieve a higher rating on the list of prioritised procurement exercises if it contributes to realising this goal. This scheme takes into consideration a procurement's economic value as well as its scope for positive impact. Where leverage to influence the market is higher, projects are also ranked higher on the list of prioritised procurement exercises (Morris 2020, p. 70). On the other hand, if the state does not recognize business efforts in public procurement exercises, it may discourage businesses from sustaining such practices (Morris 2020, p. 10).

If directly related to core business activities, the integration of human rights principles into business policy, practice, and communication, could contribute to opening new business opportunities (e.g. expanding the range of clients by including vulnerable populations if the products and services are made more accessible). Also, a company that respects human rights internally and externally can profit from a more loyal, engaged, and productive workforce, as well as avoid supply chain disruption and employee-based litigation claims (Baglayan et al. 2018, p. 21). This particularly supports business resilience in case of crisis. For instance, those companies that earlier provided opportunities for a better work-life balance to their employees by allowing for the possibility of remote working were able to adapt much more easily and quickly to the changing labour conditions brought about 


\section{ENTREPRENEURSHIP AND SUSTAINABILITY ISSUES}

ISSN 2345-0282 (online) http://jssidoi.org/jesi/ 2020 Volume 8 Number 2 (December)

http://doi.org/10.9770/jesi.2020.8.2(56)

Make your research more visible, join the Twitter account of ENTREPRENEURSHIP AND SUSTAINABILITY ISSUES: @Entrepr69728810

by the arrival of the COVID-19 pandemic, and the resulting quarantine. Surveys provide evidence that job loyalty rises as businesses address employee needs, from diversity and inclusion to sustainability and reskilling (Deloitte 2020). Apart from internal human rights issues, research confirms that inclusion and engagement with affected communities is not only a matter of mitigating risk, but can also be financially rewarding (Baglayan et al. 2018, p. 27).

\section{Conclusions}

Although researchers and international organisations acknowledge that voluntary commitments by businesses in the field of human rights do not yield effective results, the emerging binding requirements have also demonstrated drawbacks in achieving their aims. So far the existing legal requirements have had a limited effect on human rights compliance, and have served more as a 'stick' rather than a perceived 'carrot' that brings benefits for businesses.

However, the legal regulation on business and human rights needs to be viewed as something that creates opportunities - not only constraints - for businesses. The full use of such benefits can only be possible if states demonstrate strong leverage commitments to human rights requirements placed on business, for example in public procurement and other incentives, and create a positive environment for business action.

While human rights due diligence is most advanced in terms of legal regulation, so far mandatory requirements have not attained wide recognition at the national (few examples only) or the EU levels. At the same time, considering the political commitments of the EU, the prospective regulation in this area is most realistic. Its value would be enhanced both for businesses and for human rights compliance if noted drawbacks are addressed when creating the EU-wide mandatory rules on due diligence. This could include: promoting understanding of the content and the value of the requirements of due diligence, as well as the relationship between materiality and reporting, creating enforcement mechanism and possibly differentiating the requirements for small and large businesses as their capacities differ.

Expectations from companies that are turning into legal requirements - in particular on due diligence, access to capital, and non-financial reporting - are not a threat to business and are reasonable. Expecially, if we consider that ignorance of existing impact on human rights might result in financial, reputational, investor relations, or other risks and costs, such as litigation. Understanding these expectations allows companies to easier navigate the changing business environment, which would otherwise be quite alien to businesses accustomed to the previous landscape.

\section{References}

African Union Commission. (2016). Draft Pan-African Investment Code. Retrieved from https://au.int/sites/default/files/documents/32844doc-draft_pan-african_investment_code_december_2016_en.pdf

Alliance for Corporate Transparency. (2019). Research report 2019: An analysis of the sustainability reports of 1000 companies pursuant to the EU Non-Financial Reporting Directive. Retrieved from https://www.allianceforcorporatetransparency.org/assets/2019_Research_Report\%20_Alliance_for_Corporate_Transparency7d9802a0c18c9f13017d686481bd2d6c6886fea6d9e9c7a5c3cfafea8a48b1c7.pdf 


\section{ENTREPRENEURSHIP AND SUSTAINABILITY ISSUES}

ISSN 2345-0282 (online) http://jssidoi.org/jesi/ 2020 Volume 8 Number 2 (December)

http://doi.org/10.9770/jesi.2020.8.2(56)

Make your research more visible, join the Twitter account of ENTREPRENEURSHIP AND SUSTAINABILITY ISSUES: @ Entrepr69728810

Aryobsei, M., \& Scherb, M. (15 July 2020). Germany takes a step closer to mandatory human rights supply chain due diligence [Blog post]. Freshfields Bruckhaus Deringer. Retrieved from https://sustainability.freshfields.com/post/

102gbky/germany-takes-a-step-c loser-to-mandatory-human-rights-supply-chain-due-diligence

Baglayan, B., Landau, I., McVey, M. C., \& Wodajo, K. (2018). Good business: The economic case for protecting human rights [Report]. Retrieved from https://corporatejustice.org/2018_good-business-report.pdf

Barrientos, S. \& Smith, S. (2007). Do Workers Benefit from Ethical Trade? Assessing Codes of Labour Practice in Global Production Systems. Third World Quarterly, 28, 713-29. https://doi.org/10.1080/01436590701336580

Bartels, L. (2014). A model human rights clause for the EU's international trade agreements. Berlin: German Institute for Human Rights. Retrieved from https://www.institut-fuer-menschenrechte.de/uploads/tx_commerce/Studie_A_Model_Human_Rights_Clause.pdf

Bernaz, N. (2017). Business and human rights. History, law and policy - Bridging the accountability gap. London: Routledge.

Bernaz, N. (25 August 2020). The draft UN Treaty on Business and Human Rights: The triumph of realism over idealism [Blog post]. Business \& Human Rights Resource Centre. Retrieved from https://www.business-humanrights.org/en/the-draft-un-treaty-on-bus iness-andhuman-rights-the-triumph-of-realism-over-idealis m

Blekaitis, L. (10 January 2020). Atnaujinus prekybą, „Grigeo“ akcijų verte krito beveik 30 proc. [The value of Grigeo shares fell by $30 \%$ after resuming trade]. LRT. https://www.lrt.lt/naujienos/verslas/4/1132125/atnaujinus-prekyba-grigeo-akciju-verte-krito-be veik-30-proc

Bonfanti, A. (Ed.). (2019). Business and Human Rights in Europe: International Law Challenges. London: Routledge.

Buhmann, K., \& Wettstein, F. (2017). Business and human rights: Not just another CSR issue? In A. Rasche, M. Morsing, \& J. Moon (Eds.), Corporate social responsibility: Strategy, communication, governance (pp. 379-404). Cambridge: Cambridge University Press. https://doi.org/10.1017/9781316335529.024

Business \& Human Rights Resource Centre. (N.d.) Towards mandatory human rights due diligence [Blog]. Retrieved from https://www.business-humanrights.org/en/blog/?opinion_series=3\&backdate_after=\&backdate_before=\&query=

Business \& Human Rights Resource Centre. (21 April 2020a). Investors with over US $\$ 4.2$ trillion call on govts. to introduce ma ndatory human rights due diligence for companies [Story summary]. Retrieved from https:/www.business-humanrights.org/en/latestnews/investors-with-over-us42-trillion-call-on-govts-to-introduce-mandatory-human-rights-due-diligence-for-companies/

Business \& Human Rights Resource Centre. (9 June 2020b). Swiss due diligence initiative set for public referendum as Parliament only opts for reporting-centred proposal [Story summary]. Retrieved from https://www.business-humanrights. org/en/latest-news/swiss-duediligence-initiative-set-for-public-referendum-as-parliament-only-opts-for-reporting-centred-proposal/

CIDSE. (2013). Human rights due diligence: Policy measures for effective implementation. Brussels: CIDSE. Retrieved from https://media.business-humanrights.org/media/documents/files/documents/HRDD_EN_Final.pdf

Cabal and Pasini Bertran v. Australia, Communication 1020/2001, UN Doc. CCPR/C/78/D/1020/2001, 19 September 2003.

Curley, M. (3 July 2020). Human rights due diligence: Making it mandatory - and effective [Blog post]. EUIdeas. Retrieved from https://euideas.eui.eu/2020/07/03/human-rights-due-diligence-making-it-mandatory-and-effective/

Čertanec, A. (2019). The connection between corporate social responsibility and corporate respect for human rights. DANUBE: Law, Economics and Social Issues Review, 10(2), 103-127. https://doi.org/10.2478/danb-2019-0006

De Brabandere, E. (26 March 2018). Human rights and international investment law. Grotius Centre Working Paper Series, No. 2018/075HRL. Retrieved from https://ssrn.com/abstract=3149387

Deloitte. (2020). The Deloitte Global Millennial Survey 2020: Resilient generations hold the key to creating a 'better normal' [Report]. Retrieved from https://www2.deloitte.com/global/en/pages/about-deloitte/artic les/millennialsurvey.html 
ENTREPRENEURSHIP AND SUSTAINABILITY ISSUES

ISSN 2345-0282 (online) http://jssidoi.org/jesi/ 2020 Volume 8 Number 2 (December)

http://doi.org/10.9770/jesi.2020.8.2(56)

Make your research more visible, join the Twitter account of ENTREPRENEURSHIP AND SUSTAINABILITY ISSUES: @ Entrepr69728810

Dillon, M. (6 July 2020). European and American perspectives on mandatory human rights due diligence [Blog post]. KSAPA. Retrieved from https://ksapa.org/european-and-american-perspectives-on-mandatory-human-rights-due-diligence/

Directive 2014/95/EU of the European Parliament and of the Council of 22 October 2014 amending Directive 2013/34/EU as regards disclosure of non-financial and diversity information by certain large undertakings and groups. OJ L 330, 15.11.2014, 1-9. Retrieved from http://data.europa.eu/eli/dir/2014/95/oj

Directive 2014/24/EU of the European Parliament and of the Council of 26 February 2014 on public procurement and repealing Directive 2004/18/EC. OJ L 94, 28.3.2014, 65-242. Retrieved from http://data.europa.eu/eli/dir/2014/24/oj

Dubin, L. (21 December 2018). Corporate social responsibility clauses in investment treaties. Investment Treaty News. Retrieved from http://cf.iisd.net/itn/2018/12/21/corporate-social-responsibility-clauses-in-investment-treaties-laurence-dubin/

Esther Kiobel v. Royal Dutch Shell PLC, No. C-09-540972-HA ZA 17-1048, 1 May 2019, ECLI:NL:RBDHA:2019:4233. Retrieved from https://uitspraken.rechtspraak.nl/inziendocument?id=ECLI:NL:RBDHA:2019:6670

European Coalition for Corporate Justice. (23 June 2020). High time for Swiss referendum on the Responsible Business Initiative as parliament dumps compromise proposal. European Coalition for Corporate Justice. Retrieved from https://corporatejustice.org/news/16815-high-time-for-swiss-referendum-on-the-responsible-business-initiative-as-parliament-dumpscompromise-proposal

European Commission. (2015). Trade for all: Towards a more responsible trade and investment policy. Luxembourg: Publications Office of the European Union. Retrieved from https://trade.ec.europa.eu/doclib/docs/2015/october/tradoc_153846.pdf

European Commission. (2019). Commission Staff Working Document 'Corporate Social Responsibility, Responsible Business Conduct, and Business \& Human Rights: Overview of Progress’. SWD(2019) 143 final, 20.3.2019.

European Commission. (2020). Consultations on Non-financial reporting by large companies (updated rules). Retrieved from https://ec.europa.eu/info/law/better-regulation/have-your-say/initiatives/12129-Revision-of-Non-Financial-Reporting-Directive/public$\underline{\text { consultation }}$

Fundamental Rights Agency. (2019). Business-related human rights abuse reported in the EU and available remedies [Report]. Retrieved from https://fra.europa.eu/en/publication/2019/business-re lated-human-rights-abuse-reported-eu-and-available-remedies

Gregor, F., \& Houston, J. (21 August 2020). Landmark report on 1,000 European companies shows the need for human rights due diligence laws [Blog post]. Business \& Human Rights Resource Centre. Retrieved from https://www.business-humanrights.org/en/blog/landmarkreport-on-1000-european-companies-shows-the-need-for-human-rights-due-diligence-laws/

Latorre, A. F. L. (2020). In defence of direct obligations for businesses under international human rights law. Business and Human Rights Journal, 5(1), 56-83. https://doi.org/10.1017/bhj.2019.27

Lindholm, H., Egels-Zandén, N., \& Rudén,C. (2016). Do code of conduct audits improve chemical safety in garment factories? Lessons on CSR in the supply chain from Fair Wear Foundation. International Journal of Occupational and Environmental Health, 22(4), $283-291$. https://doi.org/10.1080/10773525.2016.1227036

Lithuania's Action Plan on the Implementation of the United Nations Guiding Principles on Business and Human Rights (2014). Retrieved from https://www.ohchr.org/Documents/Issues/Business/NationalPlans/Lithuania_NationalPlanBHR.pdf

Locke, R.M. (2013). The Promise and Limits of Private Power. Promoting Labor Standards in a Global Economy. Cambridge University Press. https://doi.org/10.1017/CBO9781139381840

Maastricht Guidelines on Violations of Economic, Social and Cultural Rights (4 March 1997). MCHR 97-124. Retrieved from http://hrlibrary.umn.edu/instree/Maastrichtguidelines_.html 
ENTREPRENEURSHIP AND SUSTAINABILITY ISSUES

ISSN 2345-0282 (online) http://jssidoi.org/jesi/ 2020 Volume 8 Number 2 (December)

http://doi.org/10.9770/jesi.2020.8.2(56)

Make your research more visible, join the Twitter account of ENTREPRENEURSHIP AND SUSTAINABILITY ISSUES: @Entrepr69728810

McCorquodale, R., Smit, L., Neely, S., \& Brooks, R. (2017). Human rights due diligence in law and practice. Business and Human Rights Journal, 2(2), 195-224. https://doi.org/10.1017/bhj.2017.2

Moreno Gómez v. Spain, No. 4143/02, ECHR 2004-X, 16 November 2004. ECLI:CE:ECHR:2004:1116JUD000414302.

Morris, D. (2020). Driving change through public procurement: A toolkit on human rights for procurement policy makers and practitioners. Copenhagen: The Danish Institute of Human Rights. Retrieved from https:/www.humanrights.dk/sites/humanrights.dk/files/media/document/dihr_toolkit_public_procurement_2020_webaccessible.pdf

Parella, K. (2019). Improving Human Rights Compliance in Supply Chains. Notre Dame Law Review, 95(2), 727-793. Retrieved from https://scholarship.law.nd.edu/ndlr/vol95/iss 2/5

Ramasastry, A. (2015). Corporate Social Responsibility Versus Business and Human Rights: Bridging the Gap Between Responsibility and Accountability. Journal of Human Rights, 14(2), 237-259. https://doi.org/10.1080/14754835.2015.1037953

Regulation (EU) No. 995/2010 of the European Parliament and of the Council of 20 October 2010 laying down the obligations of operators who place timber and timber products on the market. OJ L 295, 12.11.2010, 23-34. Retrieved from http://data.europa.eu/eli/reg/2010/995/oj

Regulation (EU) No. 2017/821 of the European Parliament and of the Council of 17 May 2017 laying down supply chain due diligence obligations for Union importers of tin, tantalum and tungsten, their ores, and gold originating from conflict-affected and high-risk areas. $O J$ L 130, 19.5.2017, 1-20. Retrieved from http://data.europa.eu/eli/reg/2017/821/oj

Schenk, S., Thorhauer, N. I., \& Hubert, Q. (22 July 2020). Supply Chain Law in Germany: Current steps towards a mandatory human rights due diligence law. Lexology. Retrieved from https://www.lexology.com/library/detail.aspx?g=f1 bde270-239d-40cd-85ad$\underline{\mathrm{d} 805 \mathrm{adba} 5790}$

Sustainable Business in Sweden. (N.d.). Sweden.se. Retrieved from https://sweden.se/business/sustainable-business-in-sweden/

Šaltinytè, L. (2020). International legal personality: Towards legal duties of transnational corporations? In D. Gailiūtè-Janušoné, et al. (Eds.), XXI amžiaus iššūkiai tarptautinei teisei. Liber Amicorum Sauliui Katuokai. Vilnius: Mykolo Romerio universitetas; Baltijos kopija.

United Nations Committee on Economic, Social and Cultural Rights. (2012). Concluding observations: Germany. 12 November 2012, UN Doc. CCPR/C/DEU/CO/6.

United Nations Committee on Economic, Social and Cultural Rights. (2017). General comment No. 24 (2017) on State obligations under the International Covenant on Economic, Social and Cultural Rights in the context of business activities. 10 August 2017, E/C.12/GC/24. Retrieved from https://www.refworld.org/docid/5beaecba4.html

United Nations Conference on Trade and Development. (2018). Recent developments in the international investment regime, Issue 1 [Report]. Retrieved from https://unctad.org/en/PublicationsLibrary/diaepcbinf2018d1_en.pdf

United Nations Conference on Trade and Development. (2018). World investment report 2018: Investment and new industrial policies [Report]. Retrieved from https://unctad.org/en/PublicationsLibrary/wir2018_en.pdf

United Nations Conference on Trade and Development. (2020). World investment report 2020: International production beyond the pandemics [Report]. Retrieved from https://unctad.org/en/PublicationsLibrary/wir2020_overview_en.pdf

United Nations Environment Programme Finance Initiative. (2019). Principles for responsible banking: Guidance document. Geneva: UNEP Finance Initiative. Retrieved from https://www.unepfi.org/wordpress/wp-content/uploads/2019/09/PRB-Guidance-Document-Final19092019.pdf

United Nations Working Group on Business and Human Rights. (2018). Corporate human rights due diligence-Getting started, emerging practices, tools and resources [Annex to the Working Group's General Assembly report, A/73/163]. Retrieved from https://www.ohchr.org/Documents/Issues/Business/Session18/CompanionNote2DiligenceReport.pdf 
ENTREPRENEURSHIP AND SUSTAINABILITY ISSUES

ISSN 2345-0282 (online) http://jssidoi.org/jesi/ 2020 Volume 8 Number 2 (December)

http://doi.org/10.9770/jesi.2020.8.2(56)

Make your research more visible, join the Twitter account of ENTREPRENEURSHIP AND SUSTAINABILITY ISSUES: @Entrepr69728810

United Nations Working Group on Business and Human Rights. (2020). Ensuring that business respects human rights during the Covid-19 crisis and beyond: The relevance of the UN Guiding Principles on Business and Human Rights [Press release]. United Nations Human Rights. Retrieved from https://www.ohchr.org/EN/NewsEvents/Pages/DisplayNews.aspx?NewsID=25837\&LangID=E

Urbaser and Consorcio de Aguas Bilbao v. Argentina, ICSID Case No. ARB/07/26, Award, 8 December 2016. Retrieved from http://icsidfiles.worldbank.org/icsid/ICSIDBLOBS/OnlineAwards/C255/DC9852_En.pdf

Vedanta Resources Plc and Konkola Copper Mines Plc (Appellants) v. Lungowe and Others. (Respondents), [2019] UKSC 20, 10 April 2019. Retrieved from: https://www.supremecourt.uk/cases/docs/uksc-2017-0185-judgment.pdf

Von Hannover v. Germany, No. 59320/00, ECHR 2004-VI, 24 June 2004. ECLI:CE:ECHR:2004:0624JUD005932000

Wilson, National Union of Journalists and Others v. the United Kingdom, Nos. 30668/96, 30671/96, 30678/96, ECHR 2002-V, 2 July 2002. ECLI:CE:ECHR:2002:0702JUD003066896

Lyra JAKULEVIČIENĖ holds a PhD in law and is currently a professor at the Institute of International and EU Law in the Law School of Mykolas Romeris University, Lithuania. She served as the head of the Human Rights Laboratory at Mykolas Romeris University. Her research interests include international and EU law, human rights, asylum, and migration.

ORCID ID: https://orcid.org/0000-0002-2510-1196

Dovilè GAILIŪTĖ-JANUŠONĖ holds a $\mathrm{PhD}$ in Law and currently serves as associate professor at the Institute of International and EU Law in the Law School of Mykolas Romeris University, Lithuania. She served as a trainee at the European Court of Human Rights and as a legal expert for Lithuania on the FRANET research network. Her research interests include socio-economic human rights, right to housing, freedom of religion, and the right to private life.

ORCID ID: https://orcid.org/0000-0002-0987-528X

Copyright (C) 2020 by author(s) and VsI Entrepreneurship and Sustainability Center

This work is licensed under the Creative Commons Attribution International License (CC BY).

http://creativecommons.org/licenses/by/4.0/

(c) (†) Open Access 